\title{
SOME FACTORS AFFECTING THE INVITRO GAS PRODUCTION OF SOME RUMINANTS FEEDSTUFFS
}

\author{
U. A. Nayel(1), F.M. Abo-Donia(2), B.M. Ahmed(1), E. A. Sabra(3) \\ and M. K. Raslan ${ }^{(1)}$ \\ (1) Animal Production Department, Faculty of Agriculture, Menoufia University. \\ (2) Animal Production Researches Institute, Agriculture Research Center. \\ (3) Animal Biotechnology Department, Genetic Engineering and Biotechnology Research \\ Institute, University of Sadat City.
}

Received: Jan. 2, 2019

Accepted: Mar. 2, 2019

ABSTRACT: This study was conducted to investigate some factors affecting nutritive value using fermentation gas production technique (Pressure transducer for In-vitro cumulative gas production techniques. Four buffers: (BUF1= MENKE AND STEINGASS (1988). BUF2= GOERING AND VANSEOST (1970. BUF3= THEODORUE (1993). BUF4= STEINGASS (1983)) were used with two different ratios of rumen liquid buffers: (1:2 and 1:3), two different sizes of rumen liquid for incubation $(30 \mathrm{ml}$ and $60 \mathrm{ml})$, two feedstuffs samples weights (200sw1-600sw2 $\mathrm{mg}$ ) have been investigated. Various feedstuffs were evaluated: Roughages (rice straw RS), corn stover $(S)$ ), sugar cane bagasse SCB) and Alfalfa hay $A A)$ ). Concentrate (soybean meal SBM) - cottonseed meal CSM) - concentrate feed mix CFM) and corn C) ). Results showed that the highest gas emitted was found with BUF2 (GOERING and VANSEOST (1970) and the lowest was with BUF3 (THEODORUE (1993). Differences were significant $(P<0.05)$. The degradability of OM and NDF followed the same pattern. Rumen liquor size showed a significant increase for effective gas production and DM degradability with $R L 1$ (30 $\mathrm{ml}$ rumen liquor size); whereas degradability of OM and NDF followed the same pattern. Sample size had no significant effect on gas emitted and the predicted gas production. Degradability of DM, OM, and NDF followed the same pattern. The higher effective gas production in concentrate was in high energy sources (corn) than that in protein sources. However, the highest effective gas production in low-quality roughages was reported with AA followed by SCB and RS, while it was least with CS. In general, data revealed that degradability was higher with concentrates than with roughages. With different testing factors.

Keywords: In-vitro gas production, rumen liquor, buffers, degradability.

\section{INTRODUCTION}

The methodology used to measure invitro gas production has been reviewed to determine the impacts of sources of variation on resultant gas production profiles (GPP). Current methods include measurement of gas production at constant pressure (e.g., use of gas-tight syringes), a system that is inexpensive but may be less sensitive than others thereby affecting its suitability in some situations. The principle of determining the potential rumen degradabilityl fermentability of a feed by measuring gas produced from a batch culture was first developed by Hungate (1966). Trei et al. (1970) adapted the earlier techniques by attaching a water displacement manometer to each vessel to measure the gas produced. Similarly, Jouany and Thivend, (1986); Beuvink and Spoelstra, (1992) used inverted measuring cylinders to determine the volume of water displaced. Beuvink et al. (1992) then automated this water displacement technique. 
Although the pressure transducer technique is a simple approach to estimate the fermentation kinetics of a feed, several factors in the application of the method could potentially affect the gas production profile of any feedstuff. The objective of this review is to consider these sources of variation and assess what impact they have on the GPP, how this variation may be reduced, and how results produced from one laboratory and one experiment within a laboratory, may be compared with, and extrapolated to, data from other laboratories.

\section{MATERIAL AND METHODS}

This study was conducted at Rumen Microbiology Laboratory, Animal Production Researches Institute (APRI), Agriculture Researches Center (ARC), and Nutrition Laboratory, Animal Production Department, Faculty of Agriculture, Menoufia University to investigate some factors affecting feeding value using fermentation gas production technique. Four forages (rice straw, corn stover, alfalfa hay, and sugar cane bagasse) and four concentrates (concentrate feed mixture, corn, soya bean meal, and cottonseed meal) were used. All experimental samples were chopped to pass through a $2 \mathrm{~mm}$ screen for proximate analysis (Table 1), with two weight feedstuffs $(200 \mathrm{mg}$ sw 1 and $600 \mathrm{mg}$ sw2).

Four buffers were prepared as media (BUF1= MENKE AND STEINGASS (1988). BUF2= GOERING AND VANSEOST (1970. BUF3= THEODORUE (1993). BUF4= STEINGASS (1983)) and mix with rumen liquor. The composition of solutions is shown in Table (2). Rumen liquor was collected from three rams (approximately weight $40-45 \mathrm{~kg}$ ) by stomach tube. The animals were fed on berseem hay and concentrate feed mixture (CFM 14\% CP) at a ratio of 70:30 (on a DM basis). Feed was offered to animals once daily with free access to fresh water. Rumen fluid was collected from rams and transferred immediately into pre-warmed thermos bottles after strained through two layers of cheese-cloth. Rumen fluid was manipulated under continuous flushing of $\mathrm{CO}_{2}$. Buffers were mixed with rumen liquor at the ratio of $(2: 1)$ and (3: 1) respectively (buffer to rumen fluid, v/v). A volume of $30 \mathrm{ml}$ of the mixture was added to $200 \mathrm{mg}$ of feedstuffs and a volume of $60 \mathrm{ml}$ of the mixture was added to $600 \mathrm{mg}$ of feedstuffs at $100 \mathrm{ml}$ of dark glasses each glass saturated with $\mathrm{CO}_{2}$ and tightly closed with a rubber stopper fitted with outlet valve and incubated at $39^{\circ} \mathrm{C}$ in a water bath for 72 hours. Glasses were well shaken during all incubation periods and the gas volume was recorded after 3 , $6,12,24,48$, and $72 \mathrm{~h}$ incubation by pressure transducer for In-vitro cumulative gas production techniques. Three bottles contained the buffer and rumen fluid mixture was included in each run as blank.

The complete chemical composition of the tested feeds was determined according to (AOAC, 2005). Kinetic parameters of gas production (i.e., GP) estimated by fitting GP results ( $\mathrm{mL} / \mathrm{g} \mathrm{OM}$ ) in the nonlinear regression models (NLIN), an option of SAS (2008), according to the model described by France et al., (2000): GP $=b \times\left(1-\mathrm{e}^{-c(t-L)}\right)$

where: GP is the volume of GP at time $\mathrm{t}$; $b$ is the asymptotic GP ( $\mathrm{mL} / \mathrm{g} \mathrm{OM})$; $c$ is the rate of GP $(\mathrm{ml} / \mathrm{h})$ from the slowly fermentable feed fraction $b$, and $L$ is the lag time before GP. The degradability of NDF was estimated according to (Van Soest et al., 1991).

Data of feed intake, degradability, invitro gas production kinetics, OMD, and contents of samples were subjected to the random completely design analysis using the General Linear Model (GLM) of SAS (2002). Statistical model applied for analysis was: $Y_{i j k}=\mu+S_{i}+e_{i j k}$ 
Table 1: Chemical composition of experimental feedstuffs (on DM basis)

\begin{tabular}{|l|c|c|c|c|c|c|}
\hline \multicolumn{1}{|c|}{ Item\% } & DM & CP & CF & NFE & EE & ASH \\
\hline CFM & 90.22 & 13.3 & 19.23 & 58.17 & 4.8 & 4.5 \\
\hline C & 86.5 & 7.75 & 2.23 & 80.22 & 7.5 & 2.3 \\
\hline SBM & 89.02 & 38.93 & 3.88 & 42.99 & 7.9 & 6.3 \\
\hline CSM & 90.8 & 19.68 & 10.67 & 53.52 & 6.53 & 9.6 \\
\hline RS & 89.93 & 3.25 & 35.89 & 40.16 & 6.7 & 14 \\
\hline CS & 93.05 & 3.1 & 32.31 & 50.99 & 4.6 & 9 \\
\hline AA & 89.25 & 8.31 & 29.14 & 48.95 & 4.6 & 9 \\
\hline SCB & 89.9 & 3.5 & 30.1 & 62.9 & 2 & 1.5 \\
\hline
\end{tabular}

DM: dry matter, CP: crude protein, CF: crude fiber, NFE: nitrogen-free extract, EE: either extract, CFM: concentrate feed mixture(yellow corn, soya bean meal, limestone, NACL, wheat brain, molas, undecorticated cottonseed meal "solvent extract", C: corn, SBM: soya bean meal, CSM: cottonseed meal, RS: rice straw, CS: corn Stover, AA: alfalfa hay, SCB: sugar cane bagasse.

Table 2: Composition of various buffer solutions that are used (g/l) with in-vitro gas production techniques

\begin{tabular}{|l|c|c|c|c|}
\hline \multirow{2}{*}{ Component } & \multicolumn{4}{|c|}{ Media } \\
\cline { 2 - 5 } & $\begin{array}{c}\text { Menke and } \\
\text { Steingass } \\
(1988)\end{array}$ & $\begin{array}{c}\text { Steingass } \\
(1983)\end{array}$ & $\begin{array}{c}\text { Goering and } \\
\text { van Soest } \\
(1970)\end{array}$ & $\begin{array}{c}\text { Theodorou } \\
(1993)\end{array}$ \\
\hline $\mathrm{CaCl}_{2} \cdot 2 \mathrm{H}_{2} \mathrm{O}$ & 0.013 & 0.017 & 0.016 & 0.015 \\
\hline $\mathrm{MnCl}_{2} \cdot 4 \mathrm{H}_{2} \mathrm{O}$ & $9.7 \times 10^{-3}$ & 0.015 & 0.012 & 0.011 \\
\hline $\mathrm{CoCl}_{3} \cdot 6 \mathrm{H}_{2} \mathrm{O}$ & $0.97 \times 10^{-3}$ & 0.002 & $1.25 \times 10^{-3}$ & $1.11 \times 10^{-3}$ \\
\hline $\mathrm{FeCl}_{3} \cdot 6 \mathrm{H}_{2} \mathrm{O}$ & $0.77 \times 10^{-3}$ & 0.012 & $9.96 \times 10^{-3}$ & $8.84 \times 10^{-3}$ \\
\hline $\mathrm{Na}_{2} \mathrm{HPO}_{4}$ & 1.09 & 1.43 & 1.42 & 2.09 \\
\hline $\mathrm{KH}_{2} \mathrm{PO}_{4}$ & 1.19 & 1.55 & 1.55 & 1.37 \\
\hline $\mathrm{MgSO}_{4} \cdot 7 \mathrm{H}_{2} \mathrm{O}$ & 0.12 & 0.15 & 0.15 & 0.13 \\
\hline $\mathrm{NaHCO}_{3}$ & 6.71 & 8.75 & 8.74 & 7.73 \\
\hline$\left(\mathrm{NH}_{4}\right) \mathrm{HCO}_{3}$ & 0.77 & 1.00 & 1.00 & 0.88 \\
\hline $\mathrm{Resazurin}$ & $9.87 \times 10^{-4}$ & 0.125 & $1.25 \times 10^{-3}$ & $1.11 \times 10^{-3}$ \\
\hline Na & 0.23 & 0.52 & 0.016 & $2.79 \times 10^{-4}$ \\
\hline Trypticase & 1.00 & -- & 2.50 & 2.21 \\
\hline Cysteine hydrochloride & -- & -- & 0.016 & $2.79 \times 10^{-4}$ \\
\hline
\end{tabular}

Where $Y_{\mathrm{ijk}}$ represents the general observation of chemical composition, invitro gas production kinetics, OMD, $\mu$ is the expected score, $S_{i}$ is the subject $i, S$ effect of tested treatments on the observed parameters, and $e_{\mathrm{ijk}}$ the standard error term common for all observations. Significant differences among individual means were identified using Duncan's New Multiple Range Test (1955). Mean differences were considered significant at $(P<0.05)$.

\section{RESULTS AND DISCUSSION}

Data in Table (3) present the effect of buffer source on gas production; the highest gas emitted was found with BUF2 and the lowest was with BUF3.

Table (4) show that the highest effective gas production and DM degradability were with BUF2 and the lowest values with BUF3, with significant differences $(P<0.05)$. Degradability of $O M$ and NDF followed the same pattern (Table 3), with significant differences 
$(P<0.05)$. Several media have been developed which buffer the incubation and provide relevant micro-nutrients to the microorganisms. Until now, little research has been completed on relationships between the composition of the medium and measured GP. However, comparing GP from media either rich in $\mathrm{N}$ or $\mathrm{N}$-free allows assessment of contributions of $\mathrm{N}$-containing compounds in the sample. Data in the present study revealed that buffer source affects gas production; the highest gas emitted was found with BUF2 and the lowest was with BUF3.

Wilkins (1974) described a different approach to measure fermentation kinetics in-vitro, whereby fermentation took place in a sealed vessel and gas produced was determined using a pressure transducer to measure the accumulation of pressure in the vessel headspace. This principle of measuring pressure with a sensor or transducer has been widely adopted as a simple, yet sensitive, method of determining fermentation kinetics. The simplest pressure measurement technique requires manual measurement of headspace pressure, as described by Theodorou et al. (1994). Semi- and full automation of headspace pressure recording have also been developed, as described by Pell and Schofield (1993), Cone et al., (1996), Mauricio et al. (1998a), and Davies et al. (2000). Whereas AboDonia et al. (2015) reported that cumulative gas production was maximum for moth $(P<0.05)$ fodder. The concentrations of VFAs and $\mathrm{NH}_{3}-\mathrm{N} /$ total $\mathrm{N}$ were significantly $(\mathrm{P}<0.05)$ higher in moth fodder compared to khejri. Also, a positive correlation was observed between gas production and either OM or NDF disappearance on incubation of moth fodder for $24 \mathrm{~h}$ compared to khejri.

Table (3): Effect of buffer on gas emitted and gas predicted

\begin{tabular}{|c|c|c|c|c|c|c|c|c|c|c|c|c|}
\hline \multirow{2}{*}{ Item } & \multicolumn{6}{|c|}{ Gas emitted (ml) } & \multicolumn{6}{|c|}{ Gas predicted (ml) } \\
\hline & h3 & h6 & h12 & h24 & h48 & h72 & Ph3 & Ph6 & Ph12 & Ph24 & Ph48 & Ph72 \\
\hline & $13.61^{\mathrm{ab}}$ & $24.76^{b}$ & $35.47^{b}$ & $48.26^{b}$ & $62.87^{b}$ & $73.48^{b}$ & $10.56^{\mathrm{b}}$ & $22.43^{b}$ & $33.41^{b}$ & $46.61^{b}$ & $61.40^{c}$ & $72.41^{b}$ \\
\hline BUF & $4.94^{\mathrm{a}}$ & $27.28^{a}$ & & $53.09^{a}$ & $68.62^{a}$ & $79.49^{a}$ & $12.37^{a}$ & $25.38^{a}$ & & & $67.36^{a}$ & $78.61^{a}$ \\
\hline 3UF3 & $12.91^{b}$ & $24.07^{b}$ & $35.12^{b}$ & $48.09^{b}$ & $62.52^{b}$ & $72.63^{b}$ & $11.27^{\mathrm{ab}}$ & $22.85^{b}$ & & & $61.72^{\mathrm{c}}$ & $72.07^{b}$ \\
\hline & $13.94^{\mathrm{ab}}$ & $25.55^{a b}$ & & & $64.98^{b}$ & $75.56^{b}$ & $12.30^{\mathrm{a}}$ & $24.34^{a b}$ & & & $64.18^{b}$ & $75.01^{b}$ \\
\hline$\pm \mathrm{SE}$ & 0.46 & 0.68 & 0.89 & 0.90 & 0.88 & 1.02 & 0.46 & 0.68 & 0.89 & 0.90 & 0.88 & 1.02 \\
\hline
\end{tabular}

*h = time, $\mathrm{Ph}=$ =Prediction time, BUF1= MENKE AND STEINGASS (1988). BUF2= GOERING AND VANSEOST (1970), BUF3= THEODORUE (1993), BUF4= STEINGASS (1983), SE= standard error. $a$, and $b$, values with different superscript letters within the same column are significant $(P<0.05)$.

Table ( 4 ): Effect of buffer on effective gas production and degradability of DM,OM and

\begin{tabular}{|c|c|c|c|c|c|}
\hline \multirow{2}{*}{ Item } & \multicolumn{2}{|c|}{ kinetics of gas production (ml) } & \multicolumn{3}{|c|}{ Degradability (\%) } \\
\hline & b & c & DMD & OMD & NDFD \\
\hline BUF1 & $76.71^{b}$ & $0.042^{\mathrm{a}}$ & $45.25^{b}$ & $50.08^{b}$ & $37.44^{b}$ \\
\hline BUF2 & $82.22^{\mathrm{a}}$ & $0.045^{a}$ & $49.18^{\mathrm{a}}$ & $54.42^{a}$ & $40.69^{a}$ \\
\hline BUF3 & $75.83^{b}$ & $0.043^{a}$ & $45.02^{b}$ & $49.83^{b}$ & $37.26^{b}$ \\
\hline BUF4 & $78.90^{b}$ & $0.043^{a}$ & $46.89^{\mathrm{ab}}$ & $51.89^{b}$ & $38.80^{\mathrm{ab}}$ \\
\hline$\pm \mathrm{SE}$ & 1.18 & 0.002 & 1.16 & 1.17 & 1.04 \\
\hline
\end{tabular}

${ }^{*} \mathrm{c}=$ Rate of gas production, $\mathrm{b}=$ total gas, $\mathrm{DM}=$ dry matter degradability, OM=organic matter degradability, NDF= neutral detergent fiber, BUF1= MENKE AND STEINGASS (1988). BUF2= GOERING AND VANSEOST (1970), BUF3= THEODORUE (1993), BUF4= STEINGASS (1983), SE= standard error.

a, and b, values with different superscript letters within the same column are significant $(P<0$. 
Automated GP techniques as an invitro technique, is a simple method, but interactions between fermentation end products, buffering system, and amount of gas produced are very complex (Beuvink and Spoelstra, 1992). This method detects and provides useful data on fermentation kinetics of both soluble cell contents and non-soluble fractions of feedstuffs (Getachew et al., 1997). Another advantage of this method is that it can analyze a large number of samples at one time, making the analytical capacity high (Cone et al., 1997).

It is recommended to take the rumen liquor before feeding because it is most constant in its composition and activity. It is approved to take the rumen fluid mixture from two donor animals at least as the guarantees a greater constancy of activity (Menke et al., 1979; Menke and Steingass, 1988).

Table (5) show that the highest gas emitted was with RL1 and the lowest was found with RL2.

The highest effective gas production was found with RL1 (Table 6) while the lowest was reported for RL2; on the other hand, the highest DM degradability was found with RL1 and the lowest was with
RL2. The degradability of OM and NDF followed the same pattern (Table 6). With significant differences $(P<0.05)$.

Results of Rymer et al., (2005) indicated that there was little effect of rumen liquid preparation on gas production. When Pell and Schofield. (1993) used the next percentage of rumen liquor in the medium $(5,10,20$, and $40 \%)$ and found that when the rumen liquor percent has increased the percent of alfalfa hay digestibility was increased with the best rate of maximum fiber digestion was $20 \%$. Rymer et al., (2005) reported that when rumen liquor was increased in the incubation medium, the lag time of gas production was reduced, but the volume or the rate of gas production was increased. It is known that the decrease in rumen liquor to the buffer will decrease the microbial activity; this will lead to reducing the digestibility of feeds.

Results of the effect of sample size on gas emitted are presented in Table (7). It was found that sample size had no significant effect on gas emitted. The predicted gas production followed the same pattern of gas emitted.

Table (5): Effect of rumen liquor size on gas emitted and gas predicted

\begin{tabular}{|c|c|c|c|c|c|c|c|c|c|c|c|c|}
\hline \multirow{2}{*}{ Item } & \multicolumn{6}{|c|}{ Gas emitted } & \multicolumn{6}{|c|}{ Gas predicted } \\
\hline & h3 & h6 & h12 & h24 & h48 & h72 & Ph3 & Ph6 & Ph12 & Ph24 & Ph48 & Ph72 \\
\hline $\mathbf{R L}_{1}$ & $14.71^{a}$ & $26.8^{a}$ & $38.7^{a}$ & $52.6^{a}$ & $68.5^{a}$ & $79.9^{a}$ & $12.4^{\mathrm{a}}$ & $25.1^{a}$ & $37.2^{\mathrm{a}}$ & $51.4^{\mathrm{a}}$ & $67.4^{a}$ & $79.1^{\mathrm{a}}$ \\
\hline$R_{2}$ & $12.99^{b}$ & $23.95^{b}$ & $34.7^{b}$ & $47.10^{b}$ & $60.92^{b}$ & $70.63^{b}$ & $10.81^{b}$ & $22.35^{b}$ & $33.25^{b}$ & $45.9^{b}$ & $59.8^{b}$ & $69.8^{b}$ \\
\hline \pm SE & 0.32 & 0.47 & 0.62 & 0.58 & 0.58 & 0.66 & 0.32 & 0.47 & 0.62 & 0.62 & 0.58 & 0.66 \\
\hline
\end{tabular}

*h = time, Ph =Prediction time, RL1= rumen liquor1 (30ml), RL2=rumen liquor 2(60ml), SE= standard error.

a, and b, values with different superscript letters within the same column are significant $(P<0.05)$. 
U. A. Nayel, et al.,

Table (6): Effect of rumen liquor size on effective gas production and degradability of DM, OM, and NDF

\begin{tabular}{|c|c|c|c|c|c|}
\hline \multirow{2}{*}{ Item } & \multicolumn{2}{|c|}{ kinetics of gas production (ml) } & \multicolumn{3}{|c|}{ Degradability (\%) } \\
\cline { 2 - 6 } & $\mathrm{b}$ & $\mathrm{c}$ & DMD & OMD & NDFD \\
\hline RL1 & $83.67^{\mathrm{a}}$ & $0.042^{\mathrm{a}}$ & $49.47^{\mathrm{a}}$ & $54.75^{\mathrm{a}}$ & $40.93^{\mathrm{a}}$ \\
\hline RL2 & $68.17^{\mathrm{b}}$ & $0.044^{\mathrm{a}}$ & $43.70^{\mathrm{b}}$ & $48.36^{\mathrm{b}}$ & $36.16^{\mathrm{b}}$ \\
\hline ISE & 0.76 & 0.001 & 0.80 & 0.80 & 0.72 \\
\hline
\end{tabular}

${ }^{*} \mathrm{c}=$ Rate of gas production, $\mathrm{b}=$ total gas, $\mathrm{DMD}=$ dry matter degradability, OMD=organic matter degradability, NDFD= neutral detergent fiber, RL1= rumen liquor1 $(30 \mathrm{ml})$, RL2=rumen liquor $2(60 \mathrm{ml}), \mathrm{SE}=$ standard error.

$a$, and $b$, values with different superscript letters within the same column are significant $(P<0.05)$.

Table (7): Effect of samples size on gas emitted and gas predicted

\begin{tabular}{|c|c|c|c|c|c|c|c|c|c|c|c|c|}
\hline \multirow{2}{*}{ Item } & \multicolumn{5}{|c|}{ Gas emitted(ml) } & \multicolumn{5}{c|}{ Gas predicted(ml) } \\
\cline { 2 - 12 } & h3 & h6 & h12 & h24 & h48 & h72 & Ph3 & Ph6 & Ph12 & Ph24 & Ph48 & Ph72 \\
\hline SS $_{1}$ & 13.64 & 25.15 & 36.43 & 49.54 & 64.37 & 74.86 & 11.71 & 23.70 & 35.13 & 48.50 & 63.42 & 74.20 \\
\pm SE & 0.29 & 0.43 & 0.57 & 0.58 & 0.58 & 0.67 & 0.30 & 0.43 & 0.57 & 0.58 & 0.58 & 0.66 \\
\hline SS $_{2}$ & 14.20 & 25.86 & 37.22 & 50.47 & 65.38 & 76.00 & 11.50 & 23.84 & 35.40 & 49.01 & 64.07 & 75.08 \\
\pm SE & 0.38 & 0.56 & 0.74 & 0.75 & 0.74 & 0.86 & 0.38 & 0.56 & 0.74 & 0.75 & 0.74 & 0.86 \\
\hline
\end{tabular}

*h = time of incubation, $\mathrm{Ph}=$ =Prediction time, SS1= sample size $1(200 \mathrm{mg})$, SS2=sample size 2 (600mg).

Table (8) presents the effect of sample size (SS) on effective gas production. It was obvious that no differences were found between both sizes used and the degradability of DM, OM and NDF followed the same pattern (Table 8). The effect of sample preparation on GP is important whereas using a small amount of substrate is prone to experimental error in sample weighing, but further research is required to determine the optimum preparation that mimics animal chewing. Inoculum is the single largest source of variation in measuring GPP, as rumen fluid is variable and sampling schedules, diets fed to donor animals, and ratios of rumen fluid/medium must be selected such that microbial activity is sufficiently high that it does not affect the rate and extent of fermentation. Species of donor animals may also cause differences in GP.

Table (8) show that the highest effective gas production with SW2 and the lowest effective gas production with SW1 and highest degradability of dry matter with SW2 and the lowest degradability of dry matter with SW1.

Menke and Steingass (1988) observed that a close correlation between in-vitro gas production and digestibility which the better correlation was achieved when the equation includes crude protein, crude fat, and ash content. Blümmel and Ørskov (1993) adapted gas production technique to describe the kinetics of fermentation based on the following exponential model $\left[p=a+b\left(1-e^{-C T}\right)\right]$ and to predict feed intake in cattle. The results showed that the total gas production $(a+b)$ value as described by the equation was correlated with intake (0.88), digestible dry matter intake (0.93), and growth rate (0.95) in a multiple regression model. The use of the rate of gas production $c$ value did not improve the precision of the correlation. 
Table (8): Effect of samples weight on effective gas production and degradability of DM, OM, and NDF

\begin{tabular}{|c|c|c|c|c|c|}
\hline \multirow{2}{*}{ Item } & \multicolumn{2}{|c|}{ kinetics of gas production (ml) } & \multicolumn{3}{|c|}{ Degradability (\%) } \\
\cline { 2 - 6 } & b & c & DMD & OMD & NDFD \\
\hline SW1 & 78.12 & 0.043 & 46.37 & 51.32 & 38.37 \\
ISE & 0.76 & 0.001 & 0.74 & 0.75 & 0.66 \\
\hline SW2 & 78.91 & 0.043 & 46.95 & 51.95 & 38.84 \\
ISE & 0.98 & 0.001 & 0.96 & 0.96 & 0.86 \\
\hline
\end{tabular}

* $b=$ total gas, $c=$ Rate of gas production, DMD=dry matter degradability, OMD=organic matter degradability, NDFD= neutral detergent fiber, SW1= sample weight 1 (200mg), SW2=sample weight 2 (600mg).

Tuah et al. (1996) evaluating several local Ghanaian foodstuffs and found a positive and significant correlation $(0.58$ to 0.95) between in-sacco DM degradability and in-vitro gas production.

Table (9) show that gas emitted from corn (high energy source) at almost all times of incubation was less than that emitted from protein sources (SBM, CSM, and (FM); however, within the roughage sources alfalfa hay revealed the highest gas production. Also, data of gas predicted followed the same pattern (Table 9). The highest gas production from roughages was lower than that emitted from concentrates.

The by-products poor in fiber and rich in sugars are quickly degraded by the rumen microbes (Montcho et al., 2017). Menke et al., (1979) observed that there is a high correlation between the amount of substrate and the gas produced over time. It is suggested that no more than $200 \mathrm{mg}$ of dry matter of sample should be used, but if it is poorly digestible, it could be $300 \mathrm{~g}$. The in-vitro assay of foodstuffs in rumen fluid requires careful drying (Menke and Steingass, 1988).

Generally, gas production up to $24 \mathrm{~h}$ of incubation was higher with concentrates than with roughages either emitted or predicted. It is well known that concentrates are fermented faster than the roughages thus that lead to more gas production early with concentrates while with roughages more gas production was obtained at the late time of incubation. Mertens, (1998) indication that the higherfiber diets produce gas more than the lower-fiber diets which can mean that acetate production would be more with a high-fiber diet, where fermentation of fiber acetate primarily generated and gas is produced when a substrate is fermented to generate acetate or butyrate rather than propionate. The quantity of gas produced from the in-vitro incubation of a substrate is closely related to its digestibility and consequently to its energetic value (Menke et al., 1979; Menke and Steingass 1988). The gas production data may provide a prediction of the effective organic matter degradation in-sacco (Deaville and Givens, 1998a). Van Larr et al. (1998) found differences in fermentation characteristics between hull and endosperm of full-fat Soya beans; this is possibly related to the polysaccharide composition, mainly the differences in cellulose, hemicellulose, and pectin concentration in each fraction. This work pointed out the necessity to assess the different vegetal fractions in a sample.

Table (10) show that the highest effective gas production was in concentrate with high energy (corn) than 
U. A. Nayel, et al.,

that with protein; the highest effective gas production in low-quality roughages

was reported with AA followed by SCB and RS while it was least with CS.

Table (9): Effect of feedstuffs on gas emitted and gas predicted

\begin{tabular}{|c|c|c|c|c|c|c|c|c|c|c|c|c|}
\hline \multirow{2}{*}{ Item } & \multicolumn{6}{|c|}{ Gas emitted } & \multicolumn{6}{|c|}{ Gas predicted } \\
\hline & h3 & h6 & h12 & h24 & h48 & h72 & Ph3 & Ph6 & Ph12 & Ph24 & Ph48 & Ph72 \\
\hline \multicolumn{13}{|c|}{ Concentrate (ml/g DM) } \\
\hline SBM & $18.7^{\mathrm{a}}$ & $31.7^{b}$ & $42.2^{b}$ & $53.8^{\mathrm{c}}$ & $63.9^{d}$ & $70.8^{d}$ & $16.5^{\mathrm{a}}$ & $30.4^{b}$ & $40.7^{b}$ & $52.6^{\mathrm{c}}$ & $62.1^{\mathrm{d}}$ & $70.0^{d}$ \\
\hline CSM & $17.0^{\mathrm{bc}}$ & $29.6^{c}$ & $37.7^{\mathrm{d}}$ & $47.4^{\mathrm{e}}$ & $55.7^{\mathrm{e}}$ & $63.2^{f}$ & 15.bc & $28.0^{c}$ & $36.2^{\mathrm{d}}$ & $46.2^{\mathrm{e}}$ & $54.6^{\mathrm{e}}$ & $62.4^{f}$ \\
\hline CFM & $17.9^{\mathrm{b}}$ & $34.4^{\mathrm{a}}$ & $49.2^{\mathrm{a}}$ & $61.8^{\mathrm{a}}$ & $72.4^{b}$ & $80.8^{b}$ & $15.7 b$ & $32.7^{\mathrm{a}}$ & $47.7^{\mathrm{a}}$ & $60.5^{\mathrm{a}}$ & $71.4^{b}$ & $80.0^{b}$ \\
\hline C & $16.9^{c}$ & $27.2^{\mathrm{d}}$ & $40.5^{c}$ & $50.6^{d}$ & $61.3^{d}$ & $75.8^{\mathrm{c}}$ & $14.7 \mathrm{c}$ & $25.6^{d}$ & $39.0^{c}$ & $49.4^{d}$ & $60.2^{\mathrm{d}}$ & $75.0^{\mathrm{c}}$ \\
\hline \multicolumn{13}{|c|}{ Roughages (ml/g DM) } \\
\hline AA & $14.4^{\mathrm{d}}$ & 26.3e & $41.2^{\mathrm{bc}}$ & $58.4^{b}$ & $76.5^{\mathrm{a}}$ & $89.8^{\mathrm{a}}$ & $12.1^{\mathrm{d}}$ & $24.5^{\mathrm{e}}$ & $39.7^{\mathrm{bc}}$ & $57.2^{\mathrm{b}}$ & $75.4^{\mathrm{a}}$ & $89.0^{\mathrm{a}}$ \\
\hline CS & $7.9^{f}$ & $16.0 \mathrm{~h}$ & $22.5^{\mathrm{g}}$ & $37.3^{\mathrm{g}}$ & $57.8^{\mathrm{e}}$ & $67.9^{e}$ & $5.7^{f}$ & $14.3^{h}$ & $21.0^{9}$ & $36.1^{\mathrm{g}}$ & $56.7^{\mathrm{e}}$ & $67.1^{\mathrm{e}}$ \\
\hline RS & $8.4^{f}$ & $17.6 \mathrm{~g}$ & $27.5^{f}$ & $40.7^{f}$ & $62.3^{d}$ & $73.3^{\mathrm{cd}}$ & $6.1^{f}$ & $16.0^{9}$ & $26.1^{f}$ & $39.5^{f}$ & $61.2^{\mathrm{d}}$ & $72.5^{\mathrm{cd}}$ \\
\hline SCB & $9.1^{\mathrm{e}}$ & $20.3 f$ & $32.7^{\mathrm{e}}$ & $48.8^{\text {de }}$ & $68.4^{c}$ & $80.4^{b}$ & $6.8^{\mathrm{e}}$ & $18.6^{f}$ & $31.2^{\mathrm{e}}$ & $47.6^{\text {de }}$ & $67.3^{\mathrm{c}}$ & $79.7^{\mathrm{b}}$ \\
\hline
\end{tabular}

*h = time of incubation, Ph =Prediction time, SBM, soya bean meal; CSM, cottonseed meal; CFM, concentrate feed mix; C, corn; AA, Alfalfa hay; CS, corn Stover; RS, rice straw; SCB, sugar cane bagasse.

a,b, values with different superscript letters within the same column are significant $(P<0.05)$.

Table (10): Effect of feedstuffs on effective gas production and degradability of DM, OM, and NDF

\begin{tabular}{|c|c|c|c|c|c|}
\hline \multirow{2}{*}{ Item } & \multicolumn{3}{|c|}{ kinetics of gas production (ml) } & \multicolumn{3}{|c|}{ Degradability (\%) } \\
\cline { 2 - 6 } & b & c & DMD & OMD & NDFD \\
\hline Concentrate (ml/g DM) \\
\hline SBM & $68.38^{\mathrm{e}}$ & $0.06^{\mathrm{b}}$ & $59.97^{\mathrm{a}}$ & $66.98^{\mathrm{a}}$ & $52.36^{\mathrm{a}}$ \\
\hline CSM & $60.95^{\mathrm{f}}$ & $0.06^{\mathrm{c}}$ & $57.07^{\mathrm{b}}$ & $61.24^{\mathrm{b}}$ & $51.48^{\mathrm{a}}$ \\
\hline CFM & $77.05^{\mathrm{d}}$ & $0.07^{\mathrm{a}}$ & $54.96^{\mathrm{c}}$ & $57.62^{\mathrm{c}}$ & $47.49^{\mathrm{b}}$ \\
\hline C & $76.64^{\mathrm{d}}$ & $0.04^{\mathrm{d}}$ & $54.50^{\mathrm{c}}$ & $59.00^{\mathrm{c}}$ & $29.28^{\mathrm{e}}$ \\
\hline \multicolumn{5}{|l}{} \\
\hline Roughages (ml/g DM) & \multicolumn{5}{|l}{} \\
\hline AA & $92.71^{\mathrm{a}}$ & $0.04^{\mathrm{d}}$ & $44.49^{\mathrm{d}}$ & $49.57^{\mathrm{d}}$ & $36.19^{\mathrm{c}}$ \\
\hline CS & $81.57^{\mathrm{c}}$ & $0.02^{\mathrm{g}}$ & $34.61^{\mathrm{e}}$ & $41.71^{\mathrm{e}}$ & $31.70^{\mathrm{d}}$ \\
\hline RS & $84.25^{\mathrm{bc}}$ & $0.03^{\mathrm{f}}$ & $33.85^{\mathrm{e}}$ & $37.25^{\mathrm{f}}$ & $30.96^{\mathrm{d}}$ \\
\hline SCB & $85.78^{\mathrm{b}}$ & $0.03^{\mathrm{e}}$ & $33.43^{\mathrm{e}}$ & $39.06^{\mathrm{f}}$ & $28.93^{\mathrm{e}}$ \\
\hline ISE & 1.03 & 0.001 & 0.62 & 0.70 & 0.55 \\
\hline
\end{tabular}

SBM= soya bean meal; $\mathrm{CSM}=$ cottonseed meal; $\mathrm{CFM}=$ concentrate feed mix; $\mathrm{C}=\mathrm{corn} ; \mathrm{AA}=\mathrm{Alfalfa}$ hay; $C S=$ corn Stover; $R S=$ rice straw; $S C B=$ sugar cane bagasse.

a,b, values with different superscript letters within the same column are significant $(P<0.05)$. 
In general, data revealed that degradability was higher with concentrates than with roughages. Within concentrate sources degradability of OM was highest with protein sources (SBM and CSM) while within roughages it was highest with AA than the other sources.

Khazaal et al. (1993) correlated chemical composition (i.e. CP, NDF, ADF, or $A D L)$ with in-vitro two-stage digestibility, in-sacco degradability, and gas production with voluntary intake and in-vivo apparent DM digestibility of 10 graminaceous hays in sheep. Accurate prediction of intake and in-vivo apparent DMD was achieved using NDF, ADF, ADL, and $C P$ in multiple regression. However, using the $(a+b$ and $c)$ of gas production only intake was predicted accurately. The lower performance of the gas test was attributed to the small contribution to gas production and higher buffering capacity resulting from protein fermentation.

In-vitro cumulative gas production techniques were developed to predict the fermentation of ruminant feedstuffs. A feedstuff is incubated with buffered rumen fluid as soon as gas produced is measured as an indirect indicator of fermentation kinetics. When a feedstuff is incubated with buffered rumen fluid, it is first degraded and the degraded fraction may either be fermented to produce gas and fermentation acids or incorporated into microbial biomass. When combined with measures of degradation, gas production techniques provide a measure of the proportion of feed that is fermented as opposed to that which is partitioned to microbial growth.

From a historical point of view, the invivo method has generated a lot of important knowledge about feed fermentation for different types of feeds
(Kitessa et al., 1999). This method will also be important in the future because in-vivo trials will be needed as it represents the actual animal response to dietary treatment. In the system published by Menke et al. (1979) the substrate was incubated in a calibrated gas-tight glass syringe fitted with a plunger, the gas produced over $96 \mathrm{~h}$ period is recorded. The incubation media include rumen liquor and a buffer. The main innovation in such a method was that gas production is recorded rather than degradation. The same postulate continues until today, even when the method had been simplified and improved.

The most negative aspect of this method is that it requires donor animals to supply rumen fluid, which is materially expensive (Kitessa et al., 1999). Another limitation of the GP technique is that it has a lack of standardization in the methodology, which makes it difficult to make comparisons on results between different laboratories (Williams, 2000).

Where it appeared that the dried grass negatively affects the gas production profile (Rymer and Givens, 1998). Nagadi et al., (1998) observed that the gas production profile of dried Festuca rubra for $20 \mathrm{~h}$ at $65^{\circ} \mathrm{C}$ is more closely associated with that of the fresh sample when milling is completed through $0.4 \mathrm{~mm}$ Sieve as compared to 1.0 mm. Van Larr et al., (1998) found differences in fermentation characteristics between hull and endosperm of full-fat Soya beans; this is possibly related to the polysaccharide composition, mainly the differences in cellulose, hemicellulose and pectin concentration in each fraction. Gas production rate was increased when particle size was decreased in fibrous feeds. Rymer et al., (2005) indicated that 
maize grain that was steam-flaked, rolled or left intact had the same rate and extent of gas production when it was ground through a 1-mm screen but not when it had been ground through a 4-mm screen.

\section{REFERENCES}

A.O.A.C. (2005). Official Methods of Analysis, Association of Official Analytical Chemist, Washington DC

Abo-Donia, F.M. and A.K. Nagpal (2015). In-Vitro Evaluation of Moth (Phaseolus aconitifolius) Fodder, Khejri (Prosopis cineraria) Leaves and Their Combinations in Camel. Indian $\mathrm{J}$. Anim. Nutr32.2.p192-197.

Beuvink, J. M. W., S. F. Spoelstra and R. J. Hogendorp (1992). An automated method for measuring the time-course of gas production of feedstuffs incubated with buffered rumen fluid. Neth. J. Agric. Sci., 40:401-407.

Beuvink, J.M.W and S.F. Spoelstra (1992). Interactions between substrate, fermentation end-products, buffering systems, and gas production upon fermentation of different carbohydrates by mixed rumen microorganisms in vitro. Appl. Microbiol. Biotechnol. 37(4):505-9.

Blümmel, M. and E. R. Ørskov (1993). Comparison of gas production and nylon bad degradability of roughages in predicting feed intake in cattle. Anim. Feed Sci. Technol. 40:401-407.

Cone, J.W., A.H. van Gelder, G.J.W. Visscher and L. Oudshoorn (1996). Influence of rumen fluid and substrate concentration on fermentation kinetics measured with a fully automated time related gas production apparatus. Anim. Feed Sci. Technol. 61, 113-128.

Cone, J. W., A. H. van Gelder and F. Driehuis (1997). Description of gas production profiles with a three- phasic model. Anim. Feed Sci. Technol. 61:31-45.

Davies, Z.S., D. Mason, A.E. Brooks, G.W. Griffith, R.J. Merry and M.K. Theodorou (2000). An automated system for measuring gas production from forages inoculated with rumen fluid and its use in determining the effect of enzymes on grass silage. Anim. Feed Sci. Technol. 83, 205-221.

Deaville, E. R. and D. I. Givens (1998a). Investigation of direct gas production from silage fermentation acids. Proceedings of the British Society of Animal Science. Scarborough, March 1998. p. 64.

Duncan, D. B. (1955). Multiple range and multiple $\mathrm{F}$ test J. Biometrics 11:1.

France, J., J. Dijkstra, M.S. Dhanoa, S. Lopez and A. Bannink (2000). Estimating the extent of degradation of ruminant feeds from a description of their gas production profiles observed in vitro: derivation of models and other mathematical considerations. Brit. J.I of Nutr. 83, 143-150.

Getachew, G., M. Blümmel, H. P. S. Makkar and K. Becker (1997). In vitro gas measuring techniques for assessment of nutritional quality of feeds: a review. Anim. Feed Sci. Technol. 72:261-281.

Hungate, R.E. (1966). The rumen and its microbes. New York, NY, USA: Academic Press.

Jouany, J.P. and P. Thivend (1986). In vitro effect of avoparcin on protein degradability and rumen fermentation. Anim. Feed Sci. Technol. 15, 215-229.

Khazaal, K., M. T. Denthino, J. M. Ribeiro and E. R. Ørskov (1993). A comparison of gas production during incubation with rumen contents in vitro.

Kitessa, S., P. C. Flinn and G. G. Irish (1999). Comparison of methods used to predict the in vivo digestibility of 
feeds in ruminants. Aus. J. Agric. Res. 50:825-841.

Mauricio, R. M., A. L. Abdalla, F. L. Mould, U. R. Altaf, T. Smith, E. Owen, D. I. Givens, M. S. Dhaona and M. K. Theodorou (1998a). Comparison of bovine rumen liquor and faeces as source of microorganisms for the in vitro gas production technique assessed using twelve graminaceous forages. Proceedings of the British Society of Animal Science. Scarborough, March 1998. p. 68.

Menke, K., Raab, A. Salewski, H. Steingass, D. Fritz and Schneider, W. (1979). The estimation of the digestibility and metabolizable energy content of ruminant feeding stuffs from the gas production when they are incubated with rumen liquor in vitro. J. Agric. Sci. (Camb.) 93: 217222.

Menke, K.H. and H. Steingass (1988). Estimation of the energetic feed value obtained from chemical analysis and gas production using rumen fluid. Anim. Res Dev. 28:7-55.

Mertens, D. R. (1998). Nutritional properties of carbohydrates in feeds and their roles in dairy rations. Pages 85-99 in Proc. 19th Western Canada Nutr. Conf., Univ. Saskatchewan, Saskatoon, Canada.

Montcho, M., S. Babatiunde, A. B. Aboh, V. Bougouma-Yameogo and G. A. Mensah (2017). In vitro digestibility and fermentation kinetics of agroindustrial by-products used in ruminal feeding in Benin Republic. J. Applied. Bioscience. 116: 11628-11640.

Nagadi, S., M. Herrero and N. S. Jessop (1998). A comparison of the gas production profiles of fresh and dry forage. Proceedings of the British Society of Animal Science. Scarborough, March 1998. p. 62.
Pell, A.N. and P. Schofield (1993). Computerized monitoring of gas production to measure forage digestion in vitro. J Dairy Sci. 76 (4) : $1063-73$.

Rymer, C. and D. I. Givens (1998). Relationship between the rates of production of gas and VFA during in vitro incubations of high temperature dried grass. Proceedings of the British Society of Animal Science. Scarborough, March 1998. p55.

Rymer, C., J.A. Huntington, B.A. Williams and D.I. Givens (2005). In vitro cumulative gas production techniques: history, methodological considerations and challenges. Anim. Feed Sci. Technol. 123-124(1): 9-30.

SAS Institute Inc. (2002). JMP 5 Statistical Software. NC, USA: Cary.

SAS Institute Inc. (2008). SASISTAT Software, version 9.2. SAS

Theodorou, M.K., B.A. Williams, M.S. Dhanoa, A.B. McAllan and J. France (1994). A simple gas production method using a pressure transducer to determine the fermentation kinetics of ruminant feeds. Anim. Feed Sci. Technol. 48 (3-4):185-97.

Trei, J., W. Hale and B. Theurer (1970). Effect of grain processing on in vitro gas production. J. Anim. Sci. 30, 825831.

Tuah, A. K., D. B. Okail, E. R. Ørskov, D. Kyle, W. Shand, J. F.D. Greenhalgh, F. Y. Obese and P. K. Karikari (1996). In sacco dry matter degradability and in vitro gas production characteristics of some Ghanaian Feeds. Livestock Research for Rural Development, Vol. 8, No. 1, January 1996. pp. 23-33.

Van Larr, H., S. Tamminga, B. Willians, B. Diekema, W. Burgers, D. Groeneveld and M. Hoogendoorn (1998). In vitro fermentation characteristics of Soya bean cell wall separated from hulls and endosperm. Proceedings of the 
British Society of Animal Science. Scarborough, March 1998. p. 71.

Van Soest, P. J., G. B. Robertson and B. A. Lewis (1991). Methods for dietary fiber, neutral detergent fiber, and nonstarch carbohydrates in relation to animal nutrition. J. of Dairy Sci, 74, 3583-3597.

Wilkins, J. (1974). Pressure transducer method for measuring gas production by microorganisms. Appl. Microbiol. 27, 135-140.

Williams, B.A. (2000). Cumulative gas production techniques for forage evaluation. In: Givens DI, Owen E, Axford RFE, Omed HM, editors. Forage evaluation in ruminant nutrition. Wallingford: CABI Publishing; p. 189-213. 
بعض العوامل المؤثرة على انتاج الغاز معمليا فى بعض اغذية المجترات

أسامة أبو العز نايل(")، فوزى محمد أبو دنيا(")، بركات محمد أحمد(')، إبراهيم عبد المحسن صبره(") ،

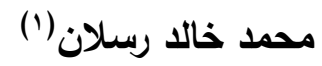

(1) قسم الإنتاج الحيوانى - كلية الززاعة - جامعة المنوفية

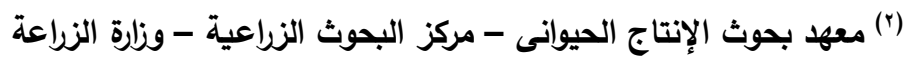

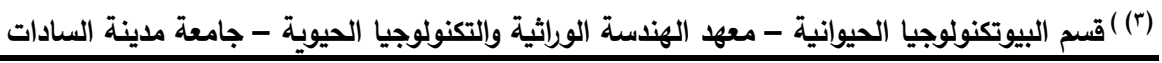

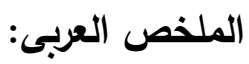

اجريت هذه الاراسة لتقييم بعض العوامل المؤثرة على القيمة الغذائية عن طريق قياس انتاج الغاز بالطريقة المعلية

باستذام جهاز (Pressure transducer for In-vitro cumulative gas production techniques)

تم استذام المنظمات الأتية :-

BUF1 = MENKE AND STEINGASS (1988)-1 (المنظم الثانى) BUF2= GOERING AND VANSEOST (1970)-2

(المنظم الثالث) BUF3 = THEODORUE (1993)-3

BUF4= STEINGASS (1983)-4

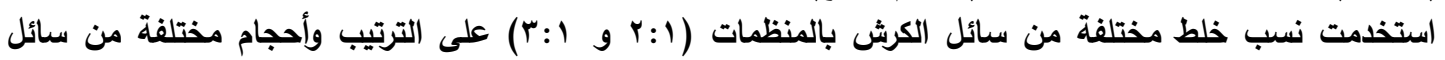

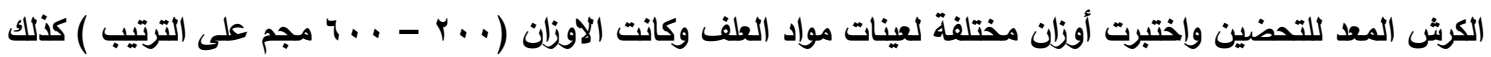

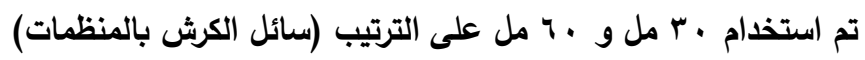

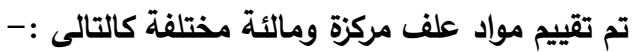

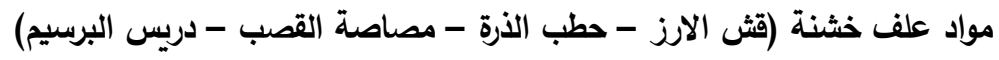
مواد علف مركزة (كسب فول الصويا- كسب بذرة القطن - ذرة صفراء -علف مصنح).

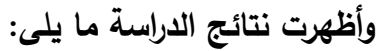

1- تأثير مصدر المنظم : سجلت أعلى كمية غاز منبعثة وكذلك اعلى معلد هضم للماندادة الجافة عذد استخدام المنظم

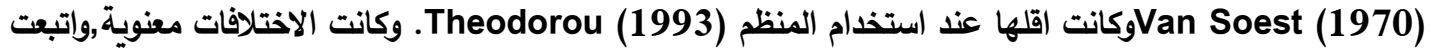

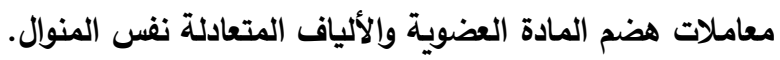

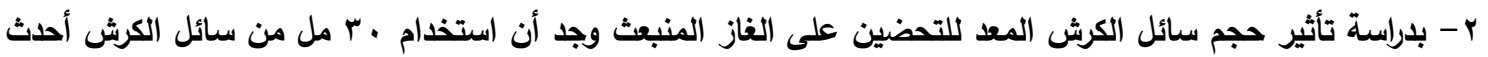

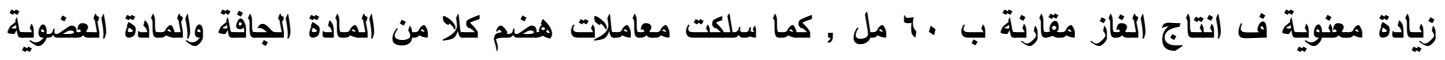

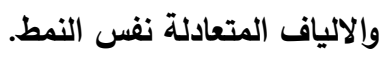
ץ- تاثير وزن العينة : لم يكن هناك تأثير معنوى لوزن العينة على كلا من حجم الغاز المنبعث او المتنبأ بانبعاثة واظظهرت

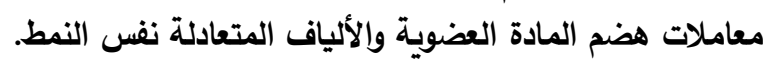

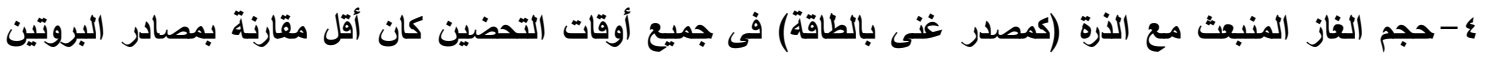
(كسب فول الصويا - كسب القطن - العلف المركز) . ه- عند مقارنة مواد العف الخثنة سجل دريس البرسيم الحجازى اكبر حجم من الغاز تبعه كلا من مصاصة القصب وقش

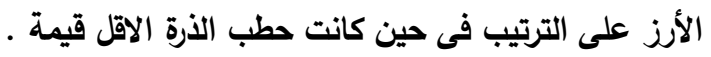

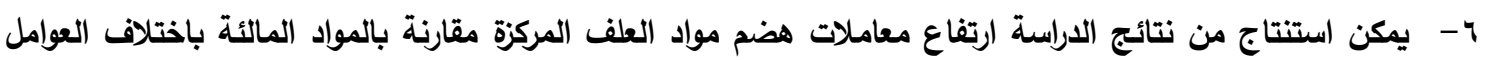
المؤثرة على انتاج الغاز معطليا.

السادة المحكمين

أ.د/ هانم عبدالرحمن الثيخ مركز البحوث الزراعية - القاهرة ، أ.د/ جمال أحمد براغيت كلية الزراعة - جامعة المنوفية 